ZHANG Jie， LIU Zhibiao，ZHENG Jianghuai

\title{
Key influencing factors of innovation activities in China's manufacturing enterprises: Evidence from Jiangsu Province
}

\author{
(C) Higher Education Press and Springer-Verlag 2009
}

\begin{abstract}
Based on empirical evidence from enterprises in Jiangsu Province, this paper studies key influencing factors of their innovation activities at the micro level. Results show that a "threshold effect" and a reversed U-shaped relationship exist between an enterprise's size and intensity of its innovation input when factors such as brand, entrepreneur background, HR, industrial and regional differences are controlled. Agglomeration effect is found influencing an enterprise's innovation activities negatively rather than positively. A non-linear relationship is also found between an enterprise's innovation activities and export ratio, showing a "capture effect". A behavior mode of the effects of these influencing factors on innovation activities of China's manufacturing enterprises is established and implications are provided.
\end{abstract}

Keywords innovation, intensity of innovation, agglomeration effect

摘要 在大量调查问卷基础上, 以江苏省制造业企业为样本, 从微观行为方式层面 考察了影响企业创新活动的关键因素。研究结果表明：在控制了品牌、企业家背景、 人力资本、行业与地区相关因素的前提下，企业规模与创新投入强度之间呈现较明 显的倒U型关系, 而且存在 “门槛效应” 。集聚效应在现阶段对企业的创新活动非

Translated and revised from Guanli shijie 管理世界 (Management World), 2007, (6): 64-74

ZHANG Jie

Business School, Nanjing University, Nanjing 210093, China

E-mail: zhangjie0402@tom.com

LIU Zhibiao

Business School, Nanjing University, Nanjing 210093, China

E-mail: zbliu@nju.edu.cn

ZHENG Jianghuai ( $\square)$

Business School, Nanjing University, Nanjing 210093, China

E-mail: zhengjh@nju.edu.cn 
但没有产生促进作用, 相反产生一定负面影响。出口因素对企业的创新活动形成了 复杂影响效应, 表现在创新活动随着出口比例而发生非线性变化, 呈现出 “俘获” 效应。在统计分析的基础上, 进一步探讨了企业产品更新与升级换代进程中的关键影 响因素和行为模式, 验证了不同规模企业的创新行为特征差异与特有的人力资本竞 争机制, 以及它们对企业创新行为的内在作用机理。

关键词 创新, 创新强度, 集聚效应

\section{Introduction and Literature review}

China has become a "world factory" since the launch of the reform and opening-up more than two decades ago. Yet if China wants to maintain a fast and sustainable economic growth, it has to shift its focus to enhancing its self-innovation capabilities rather than merely expanding its manufacturing capacities. Most of China's manufacturing enterprises, however, are still at the low-end of the global industry chain. To enhance significantly the self-innovation capabilities of China's manufacturing enterprises, it is necessary for us to identify key influencing factors of innovation activities and the behavior model of innovation. We also need to design more efficient incentive mechanisms and policies, in order to facilitate these enterprises' transfer from mere size expansion to innovation-driven expansion.

Manufacturing enterprises' innovation activities and their influencing factors have aroused continuing interests from theorists and practitioners. Ever since Schumpeter's (1942) pioneering study of size and monopoly's effects on enterprises' innovation activities, many scholars have attempted to establish a theoretical framework for enterprises' innovation behaviors and their influencing factors.

Some of the earliest and most influential works include Scherer's (1965) hypothesis of technology opportunities driving enterprise innovations and Schmookler (1966) and Utterback's (1974) hypothesis of market size driving enterprise innovation. Later, researchers have explored other elements, such as enterprise size, degree of market concentration, market power, degree of diversification, industrial characteristics, industry life circle, institutional environment, cash flow, development strategy and capability, etc., attempting to identify key influencing factors of enterprises' innovation activities. These studies, however, have not explicitly distinguish the differences between innovation capabilities and innovation behaviors. As an explanation, Cohen and Klepper (1992) argued that enterprise innovation behaviors and distribution of intensity of intra-industrial innovations might not depend on the internal or external effects of one single observable factor or multi-factors, but on a 
probabilistic process of technology capability that is difficult to observe, innovation-related and uncontrollable.

Therefore, the pursuit of behavior modes and influencing factors of enterprise innovation seems to be trapped in a dilemma of unpredictability and incomprehensibility. However, we argue, that although there are a wide array of complex influencing factors jointly affecting a firm's innovation activities (including the impact from different economic development stage and social and institutional environment), the behavioral mode and key influencing factors of enterprise innovation activities are observable under a concrete socio-economic environment, at least to certain degrees or at certain levels. For example, Yasuda (2005) studied the microstructure of Japanese manufacturing enterprises and found that enterprise size and age had certain impact on the innovation behaviors of those enterprises at the growth stage, which provided a strong foundation for our research.

Are the influencing factors of enterprise innovation activities and relevant behavioral modes vulnerable to the special impacts of external economy and macro environmental elements in developing countries with less advanced institutional environment? Discussion and research on this issue leads to a deeper understanding of the key influencing factors and behavior mode of Chinese enterprises' innovation behavior in an economic transformation period and provides a theoretical foundation for the establishment of self-innovation strategies and a system of national innovation system.

An et al. (2006) showed that industry characteristics, enterprise size and ownership characteristics were three important factors influencing manufacturing enterprises' innovation activities in China. Among them, industry characteristics were the most important one. Large enterprises with more employees, as compared to their smaller counterparts, tend to conduct more R\&D activities on a continuous basis. These enterprises are more likely to establish independent and specialized R\&D departments, while some small enterprises have also showed their unique advantages in R\&D and innovation. As a whole, enterprises of all sizes follow an obviously tilted V-shaped trajectory in their R\&D intensity. Yet An et al. also found that all the above three influencing factors had no substantive impact on the distribution of R\&D input between product innovation and process innovation. The ratio of R\&D expenditure related to product innovation remains more or less around 64\%. Foreign-funded enterprises are more active in comparison with their domestic counterparts in R\&D input and innovation activities.

Moreover, Zhu (2006) studied relative issues with a different set of samples and study approaches. He surveyed more than 800 private enterprises from 10 provinces to explore the impact of enterprise size, market power and characteristics of regional difference on enterprises' innovation activities. Results 
showed there was clearly an inverted U-shaped relationship between enterprise size and R\&D input intensity. He also found that small enterprises were more inclined to choose self-innovation style; market power (marked by their product pricing ability) and regional factors had significant impacts on $R \& D$ input intensity, while low-price competition would restrain innovative input. Besides, $\mathrm{Hu}$ (2001) found that sales revenue and government innovation expenditure had positive effects on private enterprises' R\&D input. Wu (2006) studied the relationship between enterprise $R \& D$ and productivity, and found indirectly that market factors (such as enterprise size, market concentration, entry barriers and product heterogeneity) and property structural factors had important influences on domestic enterprises' R\&D activities.

The above studies are helpful for us to understand the influencing factors of enterprises' innovation activities and their relevant behavior modes. Different from these studies, however, this paper explores the key factors from three perspectives, namely enterprise size, agglomeration effect and export ratio, to discuss what mainly influence Chinese manufacturing enterprises' innovation activities and how these factors work. First, the relationship between enterprise size and innovation activities has long been a subject of much dispute, especially in the context of China's transformational economy which is so different from that of in developed countries. Thus it is both necessary and challenging to empirically study the inherent relationship and interaction mechanism between the two. Second, industrial cluster has become the basic form and carrier of China's rise in manufacturing industry. Therefore, we need to answer whether the agglomeration effect brought forth by industrial clusters has promoted individual enterprise's innovation activities. Third, against the backdrop that China is a developing country with the largest FDI inflows and as the global manufacturing base for outsourcing, Chinese enterprises have found their niches in the global value chain by adopting export-oriented strategies and large-sized OEM production, which has greatly boosted China's manufacturing capacity in medium and low-end products. However, what impacts will this situation exert on the self-innovation activities and the development of China's national innovation system? Our questionnaire provides us with a rare opportunity to conduct empirical studies of the factors that impact China's manufacturing enterprises' innovation activities. After factors such as human capital, entrepreneurs' background, brands, industrial and regional factors were controlled, we found that there was a clearly inverted U-shaped relationship between enterprise size and intensity of innovation, revealing a "threshold effect". Quite counterintuitively, we found a negative, rather than positive impact from agglomeration effect on enterprise innovation activities. Export factors have complex effects on enterprise innovation input which changes nonlinearly with 
different export ratios, showing the existence of the "capture" effect at some stages. On the basis of statistical analysis, this paper further explores the key influencing factors in the process of product upgrades and relevant behavior modes, verifies the characteristic differences in innovation activities of enterprises with different sizes and the unique competition mechanism of human capital, as well as the internal mechanism of these factors on enterprises' innovation behaviors.

\section{Data, variables and model}

\subsection{Data and statistical analysis}

From June to December, 2006, Jiangsu Development and Reform Commission conducted a survey named "Independent Technological Innovation and Industry Upgrade for Manufacturing Enterprises of Jiangsu Province". Questionnaires were delivered to 500 enterprises, including 400 domestic enterprises and 100 foreign ones. Among them, 390 questionnaires were returned, including 342 valid ones. Geographically, 151 sampled enterprises were from the South Jiangsu, 39 from central Jiangsu and 50 from North Jiangsu. These enterprises were from 16 different manufacturing-related industries, with average fixed assets value amounting to RMB 37.56 million Yuan (data collected in 2005, values of fixed assets ranged from RMB 1.2 million to 21.6 billion Yuan).

\subsection{Variables selection and model construction}

\subsubsection{Dependent variables}

It is always difficult to choose indicators for enterprises' innovation activities. Generally, there are two types of indicators, one is input indicator such as R\&D expenditure or the number of technicians; the other is output indicators such as the number of patents or new product sales. Data collected in our research that can be used to reflect enterprises' innovation activities are expenditure on R\&D and technology in the years of 2003, 2004 and 2005. We used the quotient of an enterprise's input in R\&D and technology upgrade and its sales revenue as an indicator for technology innovation level, which we believe is a better indicator as compared with a mere use of R\&D input (Kamien and Schwartz, 1975). ${ }^{1}$ To deal with the possible lag effects, data of innovation input of the current stage,

\footnotetext{
${ }^{1}$ See Kamien and Schwatz (1979) for detailed definitions and comparison among different indicators. An et al. (2006) also used the same method.
} 
one-stage-later and two-stage-later are used as indicators of intensity of innovation to conduct compared studies.

\subsubsection{Independent variables}

First, we pay attention to the relationship between enterprise size and innovation intensity. So far, there has been little comprehensive empirical research on how does enterprise size in China affect their innovation activities. With regard to enterprise size, three commonly used indicators, namely sales revenue, total assets and the number of employees, all have their characteristic merits and demerits (Scherer, 1965). ${ }^{2}$ Thus we used these three indicators and their square roots concurrently to explore comprehensively the inner relationship between China's manufacturing enterprises' size and their innovation intensity. Besides, we set two dummy variables - the ratios of the focus enterprise's size to average foreign and domestic enterprise size respectively - to study the possible "threshold effect" of enterprise innovation activities.

Second, new economic geography (Krugman and Venables, 1995) highlights the regional diffusion and spillover of the agglomeration effect of certain technical innovation. Therefore, to study the key factors of manufacturing enterprises' innovation impetus from the cluster or agglomeration perspective is not only more applicable under the practical situation of China, but also a approach to probe into various influencing factors of enterprises' innovation activities from a more comprehensive point of view. Agglomeration effect on enterprises' innovation activities is very complex. On the one hand, agglomeration is propitious to the diffusion and spillover of innovative information in the cluster and formation of an innovative network (Chi, 2006), then it can encourage enterprises in the cluster to conduct more innovation activities; on the other hand, low-cost spillover of innovation information in the cluster may tempt enterprises to take copy-and-imitation strategy, which is likely to restrain the innovation activities of the cluster as a whole if necessary property rights protection system is lacking. To find out whether the innovation activities of China's manufacturing enterprises are enhanced or hindered, we set up a dummy variable (i.e. indicates whether the enterprise belongs to certain cluster or not) to explore the impact of cluster or agglomeration effect on China's enterprises' innovation activities at the present stage.

Third, the effect of export on China's manufacturing enterprises' innovation

\footnotetext{
${ }^{2}$ Scherer (1965) analyzed the advantages and disadvantages of these three enterprises' size indicators in detail and pointed out that they varied in the degree of accuracy when measuring enterprises' R\&D activities. So, it shall be a more comprehensive and moderate method to use these three indicators simultaneously as the measuring tools in this article.
} 
activities can not be neglected. As compared with domestic consumption market, exports are confronted with more rigorous requirements on product quality, technology and safety from the markets in developed countries. To meet these stricter demands, enterprises with higher export ratio may have a higher level of innovation intensity. However, the competition advantages of China's manufacturing enterprises are concentrated on the products characterized by low technology, low production cost and high labor intensity. A higher export ratio may lead to a manufacturing mode of low production cost and low price, which may weaken considerably these enterprises' intensity of self-innovation. We thus set up a variable denoting export ratio to explore its impact on the intensity of innovation. The square of export proportion is used for possible non-linear relationship between the two.

\subsubsection{Control variables}

Human capital accumulation and development capability of the technological personnel are the important factors affecting enterprises' second innovation activities after their self-innovation and technology absorption. We use the percentage of employees with intermediate and senior professional titles to the total number of employees, and the percentage of technicians and managers holding bachelor degrees or above to the total number of technicians and managers as two control variables of HR factors. Enterprises' innovation activities are inseparable from decision-makers' strategic orientation, while decision-makers' education and working background may impact their understanding of enterprise development strategy and innovation-related decisions. Decision-makers who have overseas working or study experience are inclined to adopt innovation strategy orientation. We thus conceive a dummy variable denoting whether a general manager or board chairman has overseas working or study experience as a control variable of entrepreneur background. Besides, it is generally believed that brands have positive effects on enterprise innovation activities, and we thus set up a dummy variable to denote whether an enterprise has its own brand as the control variable.

Furthermore, industrial difference plays an important role in enterprises' innovation activities and intensity. As our sample is heavily biased, in which textile, plastic products and machinery manufacturing, electrical apparatus, and electronic equipments manufacturing occupied $14.25 \%, 12.01 \%$ and $33.9 \%$ respectively, we set up three industry-related dummy variables as control variables. Different from extant literature, we explore in this article the differences in regional economic development inside one province to control the effects of regional differences on manufacturing enterprises' innovation intensity. Therefore, with North Jiangsu as a reference variable, we set up two dummies for 
South and Central Jiangsu ${ }^{3}$ so as to observe the impacts of different districts with varied economic development levels within one province on enterprise innovation intensity.

Definitions of the above variables are shown in Table 1.

Table 1 Definition and description of variables

\begin{tabular}{|c|c|c|c|c|}
\hline & Variables & Abbreviation & Definition & $\begin{array}{l}\text { Expected } \\
\text { signal }\end{array}$ \\
\hline $\begin{array}{l}\text { Dependent } \\
\text { variables }\end{array}$ & $\begin{array}{l}\text { Intensity of } \\
\text { technical } \\
\text { innovation }\end{array}$ & $R D I$ & $\begin{array}{l}\text { The sum of R\&D expenditure } \\
\text { for technology innovation } \\
\text { and upgrade divided by } \\
\text { Sales revenue }\end{array}$ & \\
\hline \multirow[t]{6}{*}{$\begin{array}{c}\text { Independent } \\
\text { variables }\end{array}$} & & $S I Z E 1$ & $\begin{array}{l}\text { Fixed assets (RMB } 10 \text { million } \\
\text { Yuan) }\end{array}$ & $?$ \\
\hline & & SIZE2 & $\begin{array}{l}\text { Sales revenue (RMB } 10 \text { million } \\
\text { Yuan) }\end{array}$ & $?$ \\
\hline & Enterprise size & SIZE3 & the number of employees & $?$ \\
\hline & & SIZEDUM1 & $\begin{array}{l}1 \text { for production size above } \\
\text { average abroad, equals } 0 \\
\text { otherwise }\end{array}$ & $?$ \\
\hline & & SIZEDUM2 & $\begin{array}{l}1 \text { for production size above } \\
\text { average domestic equals } \\
0 \text { otherwise }\end{array}$ & $?$ \\
\hline & Export & $E X P$ & $\begin{array}{l}\text { The ratio of sales from } \\
\text { exported products to the } \\
\text { total sales revenue }\end{array}$ & $?$ \\
\hline
\end{tabular}

\begin{abstract}
${ }^{3}$ With regard to the history and reality of its economic development, Jiangsu can be divided into three parts, namely South Jiangsu (including Wuxi, Suzhou, Changzhou, Nanjing and Zhenjiang), Central Jiangsu (including Yangzhou, Taizhou and Nantong) and North Jiangsu (including Xuzhou, Huai'an, Suqian, Yancheng and Lianyungang).

${ }^{4}$ A small number of enterprises in our survey only presented data of sales revenue from January to June in the year of 2005 , with a view to the stability of sales revenue variety which can also express increase or degrease in a more stable macro-environment and elimination of seasonal fluctuation, we use the sales revenue in 2003 and 2004 to estimate the sales revenue in 2005 in the following way:
\end{abstract}

$$
\text { Sales revenue in } 2005=\left[\begin{array}{l}
\left(\frac{(\text { Sales revenue in 2004-Sales revenue in 2003) }}{\text { Sales revenue in } 2003}+1\right) \cdot \text { Sales } \\
\text { revenue in 2004+Sales revenue from January } 2005 \text { to June } \times 2
\end{array}\right] \div 2
$$




\begin{tabular}{|c|c|c|c|c|}
\hline & Variables & Abbreviation & Definition & $\begin{array}{c}\text { Expected } \\
\text { signal }\end{array}$ \\
\hline & Aggregation & $A G G$ & $\begin{array}{l}\text { Equals } 1 \text { if belonging to a } \\
\text { certain cluster; equals } 0 \\
\text { otherwise }\end{array}$ & + \\
\hline \multirow[t]{8}{*}{$\begin{array}{l}\text { Control } \\
\text { variables }\end{array}$} & $\begin{array}{l}\text { Entrepreneur } \\
\text { background }\end{array}$ & ENT & $\begin{array}{l}\text { Indicator of entrepreneur's } \\
\text { decision-making capability. } \\
\text { It equals } 1 \text { if general } \\
\text { manager or board chairman } \\
\text { has overseas working or } \\
\text { study experience; equals } 0 \\
\text { otherwise }\end{array}$ & + \\
\hline & Human capital & $H U M 1$ & $\begin{array}{l}\text { The percentage of technicians } \\
\text { with intermediate or senior } \\
\text { professional titles }\end{array}$ & + \\
\hline & & $H U M 2$ & $\begin{array}{l}\text { The percentage of technicians } \\
\text { or managers with bachelor } \\
\text { or above academic degrees }\end{array}$ & + \\
\hline & Brand & $B R A$ & $\begin{array}{l}\text { Equals } 1 \text { if a certain brand } \\
\text { effects has been formed in } \\
\text { marketing; equals } 0 \\
\text { otherwise }\end{array}$ & + \\
\hline & $\begin{array}{l}\text { Industry } \\
\text { dummy } \\
\text { variables }\end{array}$ & $I N D 1$ & $\begin{array}{l}1 \text { for plastic manufacturing } \\
\text { industry; equals } 0 \\
\text { otherwise }\end{array}$ & $?$ \\
\hline & & $I N D 2$ & $\begin{array}{l}1 \text { for mechanical, electrical } \\
\text { appliance, and electronic } \\
\text { equipment manufacturing } \\
\text { industries; equals } 0 \\
\text { otherwise }\end{array}$ & $?$ \\
\hline & $\begin{array}{l}\text { Regional } \\
\text { dummy }\end{array}$ & $R E G 1$ & $\begin{array}{l}\text { Equals } 1 \text { if the enterprises are } \\
\text { from South Jiangsu; equals } \\
0 \text { when from North Jiangsu }\end{array}$ & $?$ \\
\hline & & $R E G 2$ & $\begin{array}{l}\text { Equals } 1 \text { if the enterprises are } \\
\text { from central Jiangsu; equals } \\
0 \text { when from North Jiangsu }\end{array}$ & $?$ \\
\hline
\end{tabular}

Based on the above rationale, we set up an econometric model as follows:

$$
\begin{aligned}
R D I_{i}= & \beta_{0}+\beta_{1} S I Z E_{i}+\beta_{2} E X P_{i}+\beta_{3} A G G_{i}+\beta_{4} S T R_{i}+\beta_{5} B R A_{i}+\beta_{6} H U M_{i}+ \\
& \sum \lambda_{j} I N D_{j}+\sum \alpha_{j} R E G_{j}+\varepsilon_{i}
\end{aligned}
$$

Here $\varepsilon$ is the random error. 


\section{Empirical results and analysis}

\subsection{Endogenous problem and determination of the lag period}

The OLS was used to analyze the cross-sectional data. First of all, special attention should be paid to multicollinearity and heteroscedasticity problems. After checking Pearson covariance matrix, we found that except enterprise size, the absolute values of other variables' coefficients were all less than 0.2 . We thus conducted regressions step by step on each size factor in order to avoid multicollinearity problem. For the purpose of solving the heteroscedasticity problem, we used the heteroscedasticity consistent covariance matrix developed by White (1980) to amend the standard error and t-value of regression, which can not only make OLS results more reliable, but somewhat eliminate the model's heteroscedasticity problem.

We used stepwise regression to combine and filter the model many times. Result showed that among all regression results which took the enterprises' intensity indicators as independent variables, the goodness-of-fit in 2005 was generally better than that of in 2004 and 2003. In other words, the factors we set have no lagged effects of innovation. Possible explanation may be that at the present stage, most China's manufacturing enterprises' innovation lies in imitation, so that enterprises' innovation input and activities concentrate mainly on short-term recoverable and competitive project, partially leading to the above insignificance lag effects. In view of this, we chose the innovation intensity in 2005 as independent variables. The regression results of 2004 and 2003 are not reported here. The measurement results of regression 2 to 5 are shown in Table 2.

Table 2 OLS regression results of the influencing factors of Chinese enterprises' innovation activities

\begin{tabular}{|c|c|c|c|c|c|c|c|}
\hline Model & 1 & 2 & 3 & 4 & 5 & 6 & 7 \\
\hline SIZE 1 & $\begin{array}{l}0.092 \\
(1.75)^{*}\end{array}$ & & & & & & \\
\hline$S I Z E 1^{2}$ & $\begin{array}{l}-2.17 \mathrm{E}-04 \\
(-1.69)^{*}\end{array}$ & & & & & & \\
\hline SIZE2 & & $\begin{array}{l}0.129 \\
(2.28)^{* *}\end{array}$ & & & & $\begin{array}{l}0.129 \\
(2.37)^{* *}\end{array}$ & \\
\hline$S I Z E 2^{2}$ & & $\begin{array}{l}-2.84 \mathrm{E}-05 \\
(-1.99)^{* *}\end{array}$ & & & & $\begin{array}{l}-6.6 \mathrm{E}-04 \\
(-2.04)^{* *}\end{array}$ & \\
\hline SIZE3 & & & $\begin{array}{l}3.077 \\
(1.51)\end{array}$ & & & & \\
\hline$S I Z E 3^{2}$ & & & $\begin{array}{l}-0.0053 \\
(-1.49)\end{array}$ & & & & \\
\hline
\end{tabular}

(To be continued) 


\begin{tabular}{|c|c|c|c|c|c|c|c|}
\hline Model & 1 & 2 & 3 & 4 & 5 & 6 & 7 \\
\hline SIZEDUM 1 & & & & $\begin{array}{l}2.116 \\
(7.58)^{* * *}\end{array}$ & & & $\begin{array}{l}3.001 \\
(8.93)^{* * *}\end{array}$ \\
\hline SIZEDUM 2 & & & & & $\begin{array}{l}1.647 \\
(2.29)^{* *}\end{array}$ & & \\
\hline EXP & $\begin{array}{l}0.0033 \\
(2.69)^{* * *}\end{array}$ & $\begin{array}{l}0.0037 \\
(2.75)^{* * *}\end{array}$ & $\begin{array}{l}0.0040 \\
(2.67)^{* * *}\end{array}$ & $\begin{array}{l}0.0044 \\
(2.70)^{* * *}\end{array}$ & $\begin{array}{l}0.0042 \\
(2.78)^{* * *}\end{array}$ & $\begin{array}{l}0.0039 \\
(2.82)^{* * *}\end{array}$ & $\begin{array}{l}0.0048 \\
(2.68)^{* * *}\end{array}$ \\
\hline$E X P^{2}$ & $\begin{array}{l}-5.10 \mathrm{E}-03 \\
(-3.05)^{* * *}\end{array}$ & $\begin{array}{l}-4.98 \mathrm{E}-03 \\
(-3.98)^{* * *}\end{array}$ & $\begin{array}{l}-5.22 \mathrm{E}-03 \\
(-3.13)^{* * *}\end{array}$ & $\begin{array}{l}-5.47 \mathrm{E}-03 \\
(-3.17)^{* * *}\end{array}$ & $\begin{array}{l}-5.19 \mathrm{E}-03 \\
(-3.032)^{* * *}\end{array}$ & $\begin{array}{l}-4.77 \mathrm{E}-03 \\
(-3.012)^{* * *}\end{array}$ & $\begin{array}{l}-5.54 \mathrm{E}-03 \\
(-3.017)^{* * *}\end{array}$ \\
\hline$A G G$ & $\begin{array}{l}-0.065 \\
(-1.422)\end{array}$ & $\begin{array}{l}-0.041 \\
(-1.389)\end{array}$ & $\begin{array}{l}-0.050 \\
(-1.413)\end{array}$ & $\begin{array}{l}-0.031 \\
(-1.572)\end{array}$ & $\begin{array}{l}-0.056 \\
(-1.402)\end{array}$ & $\begin{array}{l}-0.075 \\
(-1.384)\end{array}$ & $\begin{array}{l}-0.079 \\
(-1.412)\end{array}$ \\
\hline ENT & $\begin{array}{l}2.241 \\
(1.738)^{*}\end{array}$ & $\begin{array}{l}2.006 \\
(1.72)^{*}\end{array}$ & $\begin{array}{l}2.209 \\
(1.813)^{*}\end{array}$ & $\begin{array}{l}1.99 \\
(1.707)^{*}\end{array}$ & $\begin{array}{l}2.179 \\
(1.778)^{*}\end{array}$ & $\begin{array}{l}2.327 \\
(1.795)^{*}\end{array}$ & $\begin{array}{l}2.40 \\
(1.801)^{*}\end{array}$ \\
\hline$B R A$ & $\begin{array}{l}0.076 \\
(2.231)^{* *}\end{array}$ & $\begin{array}{l}0.115 \\
(2.107)^{* *}\end{array}$ & $\begin{array}{l}0.114 \\
(2.076)^{* *}\end{array}$ & $\begin{array}{l}0.098 \\
(1.993)^{* *}\end{array}$ & $\begin{array}{l}0.105 \\
(2.001)^{* *}\end{array}$ & $\begin{array}{l}0.120 \\
(2.349)^{* *}\end{array}$ & $\begin{array}{l}0.133 \\
(2.352)^{* *}\end{array}$ \\
\hline$H U M 1$ & $\begin{array}{l}0.029 \\
(2.11)^{* *}\end{array}$ & $\begin{array}{l}0.031 \\
(2.13)^{* *}\end{array}$ & $\begin{array}{l}0.033 \\
(1.98)^{* *}\end{array}$ & $\begin{array}{l}0.036 \\
(2.06)^{* *}\end{array}$ & $\begin{array}{l}0.032 \\
(1.99)^{* *}\end{array}$ & $\begin{array}{l}0.057 \\
(2,21)^{* *}\end{array}$ & $\begin{array}{l}0.055 \\
(2.12)^{* *}\end{array}$ \\
\hline$H U M 2$ & $\begin{array}{l}0.036 \\
(1.72)^{*}\end{array}$ & $\begin{array}{l}0.024 \\
(1.76)^{*}\end{array}$ & $\begin{array}{l}0.029 \\
(1.83)^{*}\end{array}$ & $\begin{array}{l}0.027 \\
(1.77)^{*}\end{array}$ & $\begin{array}{l}0.031 \\
(1.76)^{*}\end{array}$ & $\begin{array}{l}0.041 \\
(1.69)^{*}\end{array}$ & $\begin{array}{l}0.045 \\
(1.70)^{*}\end{array}$ \\
\hline$I N D 1$ & $\begin{array}{l}0.017 \\
(1.411)\end{array}$ & $\begin{array}{l}0.014 \\
(1.393)\end{array}$ & $\begin{array}{l}0.021 \\
(1.403)\end{array}$ & $\begin{array}{l}0.019 \\
(1.401)\end{array}$ & $\begin{array}{l}0.013 \\
(1.387)\end{array}$ & - & - \\
\hline$I N D 2$ & $\begin{array}{l}2.195 \\
(7.258)^{* * *}\end{array}$ & $\begin{array}{l}2.441 \\
(7.255)^{* * *}\end{array}$ & $\begin{array}{l}2.302 \\
(7.115)^{* * *}\end{array}$ & $\begin{array}{l}2.109 \\
(7.178)^{* * *}\end{array}$ & $\begin{array}{l}2.297 \\
(7.214)^{* * *}\end{array}$ & - & - \\
\hline$R E G 1$ & $\begin{array}{l}3.551 \\
(2.412)^{* *}\end{array}$ & $\begin{array}{l}3.121 \\
(2.337)^{* *}\end{array}$ & $\begin{array}{l}3.443 \\
(2.268)^{* *}\end{array}$ & $\begin{array}{l}3.521 \\
(2.390)^{* *}\end{array}$ & $\begin{array}{l}0.03 .220 \\
(2.271)^{* *}\end{array}$ & $\begin{array}{l}4.10 \\
(2.324)^{* *}\end{array}$ & $\begin{array}{l}4.17 \\
(2.216)^{* *}\end{array}$ \\
\hline$R E G 2$ & $\begin{array}{l}0.007 \\
(1.011)\end{array}$ & $\begin{array}{l}0.006 \\
(1.014)\end{array}$ & $\begin{array}{l}0.005 \\
(1.009)\end{array}$ & $\begin{array}{l}0.007 \\
(1.010)\end{array}$ & $\begin{array}{l}0.005 \\
(1.008)\end{array}$ & $\begin{array}{l}0.008 \\
(1.016)\end{array}$ & $\begin{array}{l}0.009 \\
(1.012)\end{array}$ \\
\hline Constant & $\begin{array}{l}2.476 \\
(16.990)^{* * *}\end{array}$ & $\begin{array}{l}2.701 \\
(17.454)^{* * *}\end{array}$ & $\begin{array}{l}2.228 \\
(15.602)^{* * *}\end{array}$ & $\begin{array}{l}2.365 \\
(16.687)^{* * *}\end{array}$ & $\begin{array}{l}2.773 \\
(18.701)^{* * *}\end{array}$ & $\begin{array}{l}3.190 \\
(19.987)^{* * *}\end{array}$ & $\begin{array}{l}3.105 \\
(19.932)^{* * *}\end{array}$ \\
\hline$F$-Value & 7.329 & 8.90 & 7.441 & 9.02 & 8.11 & 7.53 & 7.10 \\
\hline Adjusted- $R^{2}$ & 0.145 & 0.172 & 0.136 & 0.180 & 0.165 & 0.163 & 0.174 \\
\hline Sample size & 342 & 342 & 342 & 342 & 342 & 116 & 116 \\
\hline
\end{tabular}

Note: ${ }^{*},{ }^{* *},{ }^{* * *}$ indicate that the parameters' estimated values are significant at $10 \%, 5 \%$ and $1 \%$ level respectively, numbers in the parentheses represent the adjusted- $t$ values.

\subsection{Analysis of regression results}

As above, after controlling for human capital, entrepreneurs' background, brands, industrial and regional differences, and other factors' influences on enterprises' intensity of innovation, we focus exclusively on the impacts of enterprise size, 
the agglomeration effect and the proportion of exports on intensity of innovation by means of studying the samples of Jiangsu Province manufacturing enterprises.

The effects of enterprise size on innovation intensity are reviewed from Model 1 to Model 5. The regression results show that the adoption of sales revenue as an indicator of enterprise size reflects best the impact of enterprise size on innovation intensity. Model 2 indicates that there is a significant inverted $\mathrm{U}$-shaped correlation between sales revenue and innovation intensity. Meanwhile, Model 1 shows that there is also an inverted U-shaped relationship between the size of fixed assets and innovation intensity at the $10 \%$ significance level while there is no significant correlation between the number of employees and innovation intensity (see Model 3). Among existing domestic literature, our conclusion is consistent with Zhu (2006), who alleged that sales revenue and innovation intensity had a significant inverted U-shaped relationship, while different from the conclusion of An's (2006), whose study showed that there was an obvious tilted V-shaped relationship (with big opening and sharpened bottom) between the number of employees and R\&D intensity. Although our results do not demonstrate a significant relationship between the indicator of the number of employees and innovation intensity, there is still a roughly inverted U-shaped curve between them, which is quite contrary to An's findings. The reason is probably that our samples were mainly from capital and labor intensive industries with mature technology. For example, enterprises from industries of textiles, plastic products, machinery, electrical apparatus and electronic equipment manufacturing, and metal products accounted for $65.99 \%$ of the final samples. In contrast, An's samples were mainly from high-tech industries, which may be the underlying causes of such differences.

From the regression of the two dummy variables (see Model 4 and 5), the innovation intensity of enterprises (both domestic and foreign enterprises) above average production size is significantly higher than those under average. We call this phenomenon as the size "threshold effect" of enterprise innovation. In fact, enterprises with production size below average, in particular, those in industries with mature technology, are found to generally rely on copy-and-imitation strategy, pursue the short-term competitiveness of products and cost-reducing advantages, which in turn considerably lead to smaller enterprise size and poorer enterprise capability in financing, managing, market-exploiting, etc. Only after an enterprise's size has reached a certain "threshold" level and accumulated enough strength, can it give up the present imitation strategy and adopt and implement self-innovation strategy. When an enterprise has reached a certain size, on the one hand, it will face certain inertia for innovation brought forth by complex and scalization internal organizational structures; on the other hand, it falls into a dilemma caused by innovation flexibility required by increasingly 
external competition pressure and the advantages of commercialized activities. Scalization reduces not only an enterprise's sensitivity and responsivity to outside technology and market factors, but also hinders cross-departmental cooperation and technological integration as a result of strengthened bureaucratic organizational structures. Under such circumstances, enterprise size becomes a hindrance rather than a facilitator to enterprise innovation activities, embodied as an inverted U-shaped relationship between innovation and enterprise size. We use Model 2 to calculate out that the inflection point is about 22.7 billion RMB. As a majority of our samples were far smaller than that size, how to facilitate the development of those large enterprises with moderate market monopoly power to further promote their quality growth may be the key factor to nurture Chinese enterprises' innovation capabilities.

Export has mixed impacts on enterprises' innovation activities. On the one hand, enterprises engaged in OEM are compelled to improve their own innovation intensity so as to meet foreign consumers' requirements for higher quality, safety and environmental protection. On the other hand, most of China's export products are technique-mature or labor-intensive ones with cost advantages. Under the circumstances that export enterprises are "captured" by the global value chain (GVC) dominated by transnational corporations or big international buyers, China's export enterprises may be forced to lock in cost efficient production modes and technologies, which in turn restrains these enterprises' self-innovation impetus. ${ }^{5}$ Our regression result shows that export has positive effects on enterprise innovation intensity, which may result from more rigorous export requirements on product quality, safety and environment protection. But the regression result of export also shows that the relationship between export and enterprise innovation intensity takes an inversed $U$ non-linear shape. When an enterprise's export percentage reaches a certain "threshold" value, it may restrain the enterprise's innovation intensity, which may be caused by the "Capture \& Lock" effect of export on technological path and technology development ability.

Enterprise or industrial clusters have been generally regarded as the organic

\footnotetext{
${ }^{5}$ Captured GVC refers to that under GVC conditions, as the dominant force of value chains, developed countries' big buyers and multinational corporations set several parameters, including technology, quality, standard, delivery, storage and price, to restrain local outsourcers and OEMers' technology innovation and value chain ascending activities. In attempting to build independent technology innovation capabilities, brand and sale terminals, these formal outsourcers and OEMers in developing countries will threaten considerably the market monopoly power and interest of big international buyers and transnational corporations. Thus there international buyers and transnational magnates may try every means possible to restrain or control the upgrade of OEM system in developing countries. As a result, OEM system in developing countries may lock in cost-efficient production modes and technology paths, which in turn hinder their self-innovation impetus. See also Liu and Zhang (2007).
} 
carriers propitious to technology innovation diffusion and spillover (Freeman and Rothwell, 1991; DeBresson, 1999) ${ }^{6}$ because of 1) The low cost of innovation information spillover and the following technology innovation transfer, imitation, improvement and spread inside the cluster are beneficial to the reduction of uncertainty risks of new product marketerization; 2) The formation of cooperative and innovation networks within a cluster; 3 ) The sharing of all kinds of innovation facilitating institutions and public infrastructures. But our regression result shows a negative relationship between agglomeration effect and intensity of innovation, indicating that industrial clusters of Chinese manufacturing enterprises hinder rather than enhance the intensity of innovation. It may be that most so called industrial clusters in China are merely a gathering of a large number of enterprises from the same industry. In other words, most of China's "industrial clusters" are still at the preliminary stage industrial cluster development (Wang, 2004; Chen and Wang 2005). As a result, these clusters' competition advantages are mainly concentrated on low production cost factors, cost-reduction-oriented technology innovation, external diseconomies of size and other low-end competition factors, while the core competitive advantages of clusters including specialized division of labor, innovation network, brand reputation, networked cooperation and other high-end competition are not yet formed. This can explain why enterprise or industrial clusters in China at the present stage have failed to become the engines for domestic enterprises' innovation activities.

More importantly, due to the absence of effective laws and mechanisms on intellectual property protection, there is a dilemma between enterprises' innovation impetus at the micro level and spillover effects at the macro level, which is one of the important intrinsic factors of Chinese enterprises' innovation activities. It is the anticipated returns that drive individual enterprises to engage in innovation. Only when the expected revenue of innovation exceeds innovation expenditure, will enterprises be continuously motivated to engage in innovation activities. However, cluster advantages studied by lots of experts, such as low imitation barrier and spillover convenience of market, production, technology and human resources, originated from just geographical concentration. While innovation information of individual enterprise embedded in cluster's social relationship and industrial network spread fast in the whole cluster, technical

\footnotetext{
${ }^{6}$ Empirical evidence from developed countries shows that agglomeration effect is the main impetus to enterprises' innovation activities (Freeman and Rothwel, 1991; DeBresson et al., 1999). But in developing countries, agglomeration effect may have mixed impacts on enterprises' innovation activities, depending on the concrete development stage of the clusters in these countries. Generally speaking, only agglomeration effect stimulates enterprise innovation activities only in clusters with well-running self-implementation mechanisms for intellectual property protection.
} 
know-how is acquired quickly by other enterprises with low cost. Innovation benefits will be distributed rapidly within the whole cluster. Although social welfare can be enhanced in this process, individual enterprise's innovation input is very likely to be smaller than its innovation returns. Thus the best option for individual enterprises is to follow or imitate rather than to innovate. Together, these factors considerably hinder enterprises' innovation impetus in China's industrial clusters, which explains why agglomeration effect hinders rather than stimulates self-innovation activities within a cluster.

As expected, the control variables, i.e. human capital, brands, entrepreneur's background, industrial and regional differences all significantly affect enterprises' innovation intensity. Among these control variables, special attention shall be given to the industrial and regional differences. For enterprises' innovation activities, different industries mean different technology characteristics and market competition modes, resulting in different degrees of dependence of labor force, capital, technology and knowledge among different industries. Due to the space-time dynamics of industry evolution, enterprises' innovation activities are characterized by endogenetic industrial differences. Our regression results show that intensity of innovation are significantly different among different industries. Compared with the textile industry, industries of mechanical, electrical apparatus and electronic equipment manufacturing have significantly higher intensity of innovation, while there was no significant difference between plastic and textile industry. This phenomenon may have something to do with the technological requirements and characteristics of the mechanical, electrical apparatus and electronic equipment manufacturing industries.

North Jiangsu region was used as a benchmark for all models in Table 2. Both South and Central jiangsu regions were used as dummy variables to study the regional differences of Jiangsu's manufacturing enterprises in term of innovation. The regression results showed that, with other factors controlled, there was no significant difference in innovation intensity between Central and North Jiangsu, but there is a significant difference between South and North Jiangsu. Specifically, our calculation showed that enterprises' innovation intensity in South Jiangsu was 3 percent higher than that of in North Jiangsu. In our samples, enterprises' average fixed assets were 44.05 million, 34.190 million and 32.570 million Yuan in South, Central and North Jiangsu, respectively. As for the production size, 36\% of the enterprises in South Jiangsu, 28.4\% in Central Jiangsu and $26.9 \%$ in North Jiangsu were above the average production size of their foreign counterparts, and $63.4 \%$ of the enterprises in South Jiangsu, 50.1\% in Central Jiangsu and $41.9 \%$ in North Jiangsu were above the average size of their domestic counterparts. As the data shown, the number of big enterprises and their average sizes in South Jiangsu are considerably higher than that of in Central and North Jiangsu, resulting in much higher intensity of innovation of 
enterprises in South Jiangsu. These regional differences were caused by both South Jiangsu's solid industry foundations inherited from the past and its adjacency to Shanghai, China's economic centre. As a result, many high-tech multinational companies choose to settle down in South Jiangsu. The formed industry chains and technology spillover mechanisms are beneficial to domestic enterprises' innovation, learning and growth.

\subsection{Robustness test}

Cohen, Levin and Mowery (1987) found that about half of the difference of enterprises' innovation input is caused by industry fixed effects stemmed from differences in technology characteristics in an industry. Scott (1984) indicated that $16 \%$ of the difference in innovation input can be explained by an industry's technology or its life circle characteristics. Considering this situation, studying deeply into the key factors of idiographic industrial enterprises' innovation activities should be an effective method to test if it's robust or not. Model 6 and 7 in Table 2 demonstrate the respective regression results of mechanical, electrical apparatus and electronic equipment manufacturing industries (only the main results are listed due to space limit), the sign and significance of which are consistent with that of the total sample, indicating that our conclusions are reliable to a large extent.

Considering the possible effects of non-randomicity and abnormal values in the samples, we retested the robustness of our samples after eliminating the top $5 \%$ and bottom 5\% sampled enterprises, the regression results of which were consistent with that of the total sample. Besides, we conducted regression with samples from South, Central, and North Jiangsu regions respectively, and the results were also in line with the total sample (regression results are not presented here due to space limit).

\section{Further analysis}

In our questionnaire, there are a set of specially-designed questions as follows: "How does your company improve its development ability during the process of product innovation or upgrade?" "What power or resources does your company rely on for product innovation or upgrade?" and "What is the biggest difficulty that your company encounters in product innovation or upgrade?" Answers to these questions (together with other data collected from our comprehensive survey) were used to find out which factors (and at which level) are important to domestic manufacturing enterprises' innovation impetus and product upgrade capability and the relevant endogenetic mechanism. In 
other words, we are interested in finding out the specific paths of certain internal/external factors hinder/facilitate Chinese manufacturing enterprises' innovation impetus or product upgrade capability. By identifying and analyzing these key influencing factors, we hope to find out the specific behavior modes of China's manufacturing enterprises and provide suggestions for relevant policy-makers.

4.1 Identification and analysis of the key factors influencing manufacturing enterprises' product innovation and upgrade

As shown in Table 3, China's manufacturing enterprises take the following four paths to improve their innovation and R\&D capabilities, namely 1) increase in technique-upgrading investment, 2) introduction of key technicians, 3) increase in R\&D expenditure, and 4) promotion of technical training programs. About $88 \%$ and $63 \%$ of enterprises choose Path 1 and 2, respectively. Only 57.89\% of the sampled enterprises chose Path 3, showing that most of Chinese manufacturing enterprises improve their product innovation and upgrade capabilities by purchasing new manufacturing equipments or by hunting talents from their competitors, rather than by cultivating R\&D capabilities of their own. We also found that for most Chinese manufacturing enterprises, joint venture is not the major means of acquiring product innovation and upgrade capabilities. Thus the spillover effects and learning-facilitating functions of FDI on the improvement of domestic enterprises' technology innovation capabilities may not as important as we expected. Our survey showed that 1) small enterprises in comparison with big or medium-sized enterprises rely more on Path 2 to improve their product development capabilities; 2) big and medium-sized enterprises in comparison with small enterprises are prone to choose Path 3; 3) big enterprises in comparison with small and medium-sized enterprises are likely to highlight the importance of technology purchase to enhance their product-developing capabilities.

Table 3 How does the company increase its product-developing capabilities during the course of product-upgrading process.

\begin{tabular}{|c|c|c|c|c|c|c|c|c|}
\hline \multirow{2}{*}{$\begin{array}{l}\text { Factors (in descending } \\
\text { order of impact } \\
\text { factors) }\end{array}$} & \multicolumn{3}{|c|}{ Region } & \multicolumn{3}{|c|}{ Firm size* } & \multirow[t]{2}{*}{ Total } & \multirow[t]{2}{*}{ Percentage } \\
\hline & $\begin{array}{l}\text { South } \\
\text { Jiangsu }\end{array}$ & $\begin{array}{l}\text { Central } \\
\text { Jiangsu } \\
\end{array}$ & $\begin{array}{l}\text { North } \\
\quad \text { Jiangsu } \\
\end{array}$ & Large & $\begin{array}{l}\text { Medium } \\
\text { sized }\end{array}$ & - Small & & \\
\hline $\begin{array}{l}\text { Increase in } \\
\text { technique-upgrading } \\
\text { investment }\end{array}$ & 194 & 44 & 64 & 57 & 149 & 96 & 302 & 88.30 \\
\hline $\begin{array}{l}\text { Introduction of key } \\
\text { technicians }\end{array}$ & 125 & 41 & 50 & 38 & 75 & 103 & 216 & 63.16 \\
\hline
\end{tabular}




\begin{tabular}{|c|c|c|c|c|c|c|c|c|}
\hline & & & & & & & & (Continued) \\
\hline Factors (in descending & & Region & & & Firm size & & Total & Percentage \\
\hline $\begin{array}{l}\text { order of impact } \\
\text { factors) }\end{array}$ & $\begin{array}{l}\text { South } \\
\text { Jiangsu }\end{array}$ & $\begin{array}{c}\text { Central } \\
\text { Jiangsu }\end{array}$ & $\begin{array}{l}\text { North } \\
\text { Jiangsu }\end{array}$ & Large & $\begin{array}{l}\text { Medium } \\
\text { sized }\end{array}$ & Small & & \\
\hline $\begin{array}{l}\text { Increase in } \mathrm{R} \& \mathrm{D} \\
\text { expenditure }\end{array}$ & 128 & 26 & 44 & 46 & 109 & 41 & 198 & 57.89 \\
\hline $\begin{array}{l}\text { Promotion of technical } \\
\text { training programs }\end{array}$ & 128 & 30 & 27 & 57 & 92 & 36 & 185 & 54.09 \\
\hline $\begin{array}{l}\text { Increase in } \\
\text { technicians' } \\
\text { remunerations }\end{array}$ & 80 & 20 & 20 & 42 & 63 & 15 & 120 & 35.08 \\
\hline Technology purchase & 39 & 22 & 24 & 41 & 41 & 3 & 85 & 24.85 \\
\hline Joint venture & 38 & 8 & 13 & 29 & 29 & 1 & 59 & 17.25 \\
\hline $\begin{array}{l}\text { Strengthen technology } \\
\text { exchange with } \\
\text { overseas OEM } \\
\text { consignors }\end{array}$ & 40 & 6 & 6 & 3 & 31 & 18 & 52 & 15 \\
\hline Others & 5 & 4 & 0 & 2 & 6 & 1 & 9 & 2.63 \\
\hline Total & 215 & 56 & 71 & 57 & 162 & 123 & 342 & \\
\hline
\end{tabular}

Note: * indicates that total fixed assets are used as a benchmark for enterprise size. Sampled enterprises are divided into different categories based on the following standards: big enterprise (fixed assets $\geqslant$ RMB 1 billion Yuan); medium-sized enterprise ( 1 billion $>$ fixed assets $\geqslant 40$ million); small enterprises (fixed assets $<40$ million), the same hereinafter.

Table 4 describes how do China's manufacturing enterprises accomplish their product innovation and upgrade, namely by improving their technology capabilities or by hunting key technicians from other rival companies. As high as $91.52 \%$ of the sampled enterprises chose the first method while $54.39 \%$ the second one. Less than $30 \%$ of the sampled enterprises chose to cooperate with scientific research or academic institutes both at home and abroad, or engage in joint research programs with other enterprises, or purchase relevant foreign or domestic patents. Among them, only $13.72 \%$ sampled enterprises purchased domestic patents, which greatly limits the development of domestic scientific research or academic institutes. Also, this phenomenon reflects, to a certain degree, that the research of China's research centers or universities do not meet enterprises' actual requirements, thus difficult to be transferred into productivity. In contrast, in developed countries, particularly in U.S., purchase of domestic patents has become the most important means of strengthening enterprises' innovation and product upgrade capabilities (Griliches, 1984). Harryson (2004) studied Japan's technology and innovation system and found that it was the core for Japan's lead position in technical development and innovation to change from 
seeking know-how to seeking know-who. It shows that most of China's manufacturing enterprises still adopt a low-leveled, non-cooperative and inefficient innovation model and imitation strategy. Specifically, we found that 1) small enterprises are more likely to hunt key technicians from other enterprises than their medium-sized and large counterparts, with respective percentages of $74.8 \%, 51.24 \%$ and $19.3 \%$; 2) large enterprises are more inclined to cooperate with scientific academies and research institutes both at home and abroad; 3) compared to small enterprises, large enterprises pay more attention to tackle key technology problems in cooperation with other enterprises, while the potentials of small enterprises' innovation network and cooperated R\&D behaviors have not been brought into full play at the present stage; 4) although China's manufacturing enterprises buy less domestic and foreign patents to gain technological innovation capabilities in comparison with their counterparts in developed countries, the percentage of large enterprises buying foreign patents amounted to $63.16 \%$, much higher than small enterprises $(7.32 \%)$ and medium-sized enterprises (21.6\%). But the percentages of enterprises which acquired product upgrade capabilities by means of purchasing domestic patents were $42.1 \%$ for large enterprises, $13 \%$ for medium-sized enter0prises and $1.6 \%$ for small enterprises, respectively.

Table 4 What strengths or resources does the corporation rely on in achieving product innovation or upgrading.

\begin{tabular}{|c|c|c|c|c|c|c|c|c|}
\hline \multirow{2}{*}{$\begin{array}{l}\text { Factors (in descending } \\
\text { order of impact } \\
\text { factors) }\end{array}$} & \multicolumn{3}{|c|}{ Regions } & \multicolumn{3}{|c|}{ Firm size } & \multirow[b]{2}{*}{ Total } & \multirow[b]{2}{*}{ Percentage } \\
\hline & $\begin{array}{l}\text { South } \\
\text { Jiangsu }\end{array}$ & $\begin{array}{l}\text { Central } \\
\text { Jiangsu }\end{array}$ & $\begin{array}{l}\text { North } \\
\text { Jiangsu }\end{array}$ & Large & Middle & Small & & \\
\hline Our own technology & 199 & 48 & 66 & 57 & 135 & 121 & 313 & 91.52 \\
\hline $\begin{array}{l}\text { By hunting key } \\
\text { technicians from } \\
\text { other enterprises }\end{array}$ & 129 & 27 & 30 & 11 & 83 & 92 & 186 & 54.39 \\
\hline $\begin{array}{l}\text { Cooperate with } \\
\text { domestic scientific } \\
\text { research academies }\end{array}$ & 61 & 13 & 24 & 50 & 40 & 8 & 98 & 28.65 \\
\hline $\begin{array}{l}\text { Purchase relevant } \\
\text { foreign patents }\end{array}$ & 44 & 17 & 19 & 36 & 35 & 9 & 80 & 23.39 \\
\hline $\begin{array}{l}\text { Tackle key problems in } \\
\text { cooperation with } \\
\text { other enterprises }\end{array}$ & 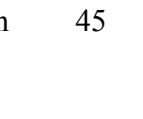 & 9 & 23 & 38 & 38 & 1 & 77 & 22.51 \\
\hline $\begin{array}{l}\text { Cooperate with foreign } \\
\text { scientific research } \\
\text { academies }\end{array}$ & 42 & 14 & 16 & 35 & 36 & 1 & 72 & 21.05 \\
\hline
\end{tabular}


(Continued)

\begin{tabular}{|c|c|c|c|c|c|c|c|c|}
\hline \multirow{2}{*}{$\begin{array}{l}\text { Factors (in descending } \\
\text { order of impact } \\
\text { factors) }\end{array}$} & \multicolumn{3}{|c|}{ Regions } & \multicolumn{3}{|c|}{ Firm size } & \multirow{2}{*}{\multicolumn{2}{|c|}{ Total Percentage }} \\
\hline & $\begin{array}{l}\text { South } \\
\text { Jiangsu }\end{array}$ & $\begin{array}{l}\text { Central } \\
\text { Jiangsu }\end{array}$ & $\begin{array}{l}\text { North } \\
\text { Jiangsu }\end{array}$ & Large & Middle & Small & & \\
\hline $\begin{array}{l}\text { Purchase relevant } \\
\text { domestic patents }\end{array}$ & 24 & 10 & 13 & 24 & 21 & 2 & 47 & 13.72 \\
\hline Total & 215 & 56 & 71 & 57 & 162 & 123 & 342 & \\
\hline
\end{tabular}

4.2 Identification and analysis of the key factors restraining manufacturing enterprises' product innovation and upgrade

We also sorted out the main factors that restrain enterprises' product innovation and upgrade activities (see Table 5). As a whole, there are two key factors: one is lack of key technicians (61.23\%) and the other is lack of funds (56.67\%). Our survey showed that the lack of senior technical personnel has become the bottleneck of Chinese manufacturing enterprises' R\&D, with a lack of funds comes next. Consequently, on the one hand, the low-cost, low-price competition and imitation strategy adopted by most of Chinese manufacturing enterprises can not provide them with the "Schumpeterian profit" gained by monopoly on innovation, which in turn further damage these enterprises' sustainable R\&D capabilities for lacking sufficient funds; on the other hand, the lack of the capital market for technology innovation and technology trade has failed to give strong financial support to emerging technology innovations as the most important function of capital market is not to provide funds for mature companies but to for newly-emerged companies. Hence, a combination of technology innovation and social capital is the main and effective solution to products and markets incubation, which lies in the core of the national innovation system in developed countries such as the States. Thereby, it has come to be one of the key factors to effectively train key technicians that meet the practical requirements of enterprises and to cultivate multi-leveled capital markets characterized by harmonious development of securities markets and venture funds, so as to prompt and sustain Chinese enterprises' self-innovation capabilities. By comparing different sized enterprises, we found that 1) the negative influence from lack of key technical personnel and funds on the product innovation and upgrade of medium-sized and small enterprises is much greater than that of on large enterprises; 2) compared with large enterprises, small enterprises have less chances and strength to cooperate with other enterprises or research academies to tackle key technology problems; and 3) government's policy has only limited effects on enterprises' product innovation and upgrade, irrespective of the size of an enterprise, which indicats that enterprises decide their own innovation behaviors on a rational basis. 
Table 5 What are the biggest difficulties the company faces in product innovation and upgrade.

\begin{tabular}{|c|c|c|c|c|c|c|c|c|}
\hline \multirow{2}{*}{$\begin{array}{l}\text { Factors (in descending } \\
\text { order of impact } \\
\text { factors) }\end{array}$} & \multicolumn{3}{|c|}{ Region } & \multicolumn{3}{|c|}{ Firm size } & \multicolumn{2}{|c|}{ Total Percentag } \\
\hline & $\begin{array}{l}\text { South } \\
\text { Jiangsu }\end{array}$ & $\begin{array}{l}\text { Central I } \\
\text { u Jiangsu }\end{array}$ & $\begin{array}{l}\text { North } \\
\text { Jiangsu }\end{array}$ & Large & Middle & Small & & \\
\hline Lack of key technicians & 129 & 29 & 51 & 13 & 92 & 104 & 209 & 61.11 \\
\hline Lack of funds & 111 & 32 & 44 & 6 & 74 & 107 & 187 & 54.68 \\
\hline $\begin{array}{l}\text { Lack of technology for } \\
\text { manufacturing } \\
\text { quipments' upgrading }\end{array}$ & 74 & 17 & 16 & 11 & 31 & 65 & 107 & 31.29 \\
\hline $\begin{array}{l}\text { Lack of partners to } \\
\text { tackle key problems }\end{array}$ & 75 & 18 & 12 & 7 & 41 & 47 & 105 & 30.7 \\
\hline $\begin{array}{l}\text { Lack of effective help from } \\
\text { universities or scientific } \\
\text { research institutes }\end{array}$ & 66 & 17 & 16 & 3 & 34 & 62 & 99 & 28.95 \\
\hline $\begin{array}{l}\text { Lack of information } \\
\text { channels for new } \\
\text { technology and markets }\end{array}$ & 55 & 11 & 11 & 2 & 31 & 34 & 77 & 22.51 \\
\hline $\begin{array}{l}\text { Difficult to sell key } \\
\text { technology }\end{array}$ & 29 & 9 & 10 & 3 & 22 & 23 & 48 & 14.04 \\
\hline $\begin{array}{l}\text { Lack of effective } \\
\text { government policies }\end{array}$ & 16 & 7 & 6 & 1 & 13 & 15 & 29 & 8.48 \\
\hline Total & 215 & 56 & 71 & 57 & 162 & 123 & 342 & \\
\hline
\end{tabular}

As above, all important variables are related to the factor of key technicians, which are essential to understand Chinese enterprises' innovation behaviors at the current stage. A common phenomenon in China is that when a certain enterprise successfully develops a new product either by investing heavily in $\mathrm{R} \& \mathrm{D}$ or by purchasing new equipments or technology absorption and make good money in a new market, there are always a large number of enterprises crowding into this emerging market. These followers usually adopt imitation strategies, such as purchasing latest equipments or hunting key technicians from rival enterprises. The low cost competition comes into being and results in China's typical technology spillover and diffusion mode. The imitation, which is one of the keys to the realization of low cost competition, is basically a combination of flow of key technical talents and dynamic import of manufacturing equipments.

The interflow of technical talents among different enterprises is one of the main modes for Chinese manufacturing enterprises' innovative technology learning and diffusion, low cost competitiveness formation and new enterprise expansion. However, the negative effects of such a mode show more clearly when enterprises reach the stage in which technology innovation has become the 
main drive behind sustainable development and industrial upgrade. Without an effective knowledge isolating mechanism (here knowledge isolating mechanism may either come from the difficulty to imitate caused by implicitness, size or heterogeneity of innovation knowledge or high cost barrier, or from governmental regulations or law barrier, namely intellectual property protection), plus low technology barriers for manufacturing enterprises, whoever with sufficient funds can enter this industry at will, which makes the manufacturing industry vulnerable to excessive entries and vicious low price competition. Moreover, as China's government exerts more rigorous regulations on the entry into new sectors of service and manufacturing industries, huge number of so called "standard enterprises" have to congregate in manufacturing or service industries characterized by low technology and labor intensity. Excessive low cost competitions make China's enterprises small in size and thus fail to gain "Schumpeterian profit", which in turn impact negatively these enterprises' sustainable technology innovation capabilities. Though low cost competition can boost China's economic growth and factor market development, the consumption of production factors is not healthy to a large extent: In the context of abnormal low prices for production factors such as land, labor force, natural resources, environment protection and taxation, there are always countless enterprises swarming into an emerging industry, resulting in seriously superfluous production capability in that industry and consequent low cost vicious competition. Most enterprises have to turn to low-cost expansion to survive. During the course of this vicious cycle of technical talents flow-imitation-low cost competition, Chinese manufacturing enterprises' acquirement and development of self-innovation capability has been greatly constrained. This phenomenon is particularly conspicuous in most of China's industrial clusters, which explains why we found the in the above empirical studies a negative relationship between the dummy variable of agglomeration effect and the intensity of innovation.

\section{Conclusions}

Based on large sample survey, this paper studies empirically the impacts of firm size, export and agglomeration effect on enterprises' innovation activities, and further probes into key influencing factors and behavioral patterns during the process of product innovation and upgrade. Main conclusions are listed as follows:

First, there is a significant inverted U-shaped relationship between enterprise size measured by sales revenue and enterprise's innovation intensity. There is 
also a visible inverted U-shaped relationship between enterprise size as measured by fixed assets and enterprises' innovation intensity. Yet there is no significant relationship between enterprise size as measured by the number of employees and innovation intensity. All these indicate that enterprise expansion in terms of fixed assets and sales revenues are critical to the cultivation of independent innovation capabilities, although such facilitating effects decrease as an enterprise grows. In reality, there exists a "threshold effect" of self-innovation size among enterprises in traditional industries with mature technology. Only when an enterprise's size has reached such a "threshold" and accumulated enough competitive capabilities, can it give up this imitation-and-copy strategy and turn to self-innovation strategy.

Second, quite counterintuitively, our empirical results indicate that agglomeration effect has both advantageous and disadvantageous impacts on enterprise's innovation intensity. Although industrial cluster has been widely considered to be an organic carrier conductive to innovation, most of China's industrial clusters restrain and block enterprises' innovation activities. It is because 1) most China's industrial clusters are still at the preliminary stage of cluster development; 2) the negative feedback impact of technology spillover characterized by HR flow on enterprises' innovation activities.

Third, one of the important findings in this article is that there is an inverted U-shaped nonlinear relationship between enterprise export and innovation intensity. The rigorous requirements from developed countries on product quality, technology and safety have played certain positive effects on Chinese manufacturing enterprises' innovation intensity. However, since the competitive advantages of China's manufacturing products mainly lie in low-end technology, low-cost and labor-intensive products, higher export percentages may compel enterprises to be locked in a low-cost, low price production mode, which in turn weakens these enterprises' intensity of self-innovation.

Fourth, consistent with our prediction, industrial and regional differences also have significant impacts on enterprise's innovation intensity. In the high-tech industries, enterprises are more inclined to innovate independently. While in the traditional industries with mature technology, enterprises prefer to purchase technology and imitate others at low cost. Enterprises in the developed regions have much stronger self-innovation and technology development capabilities as compared with their counterparts in developing areas. Even inside a region with unbalanced economic levels, this regional difference is still obvious.

Fifth, we statistically analyze the key influencing factors in the process of enterprise's product innovation and upgrade, as well as its behavioral patterns. Our results validate the presence of innovation characteristic differences among different-sized manufacturing enterprises and the impact of specific 
"human resource flow-imitation-low-cost competition strategy" on Chinese enterprise's innovation behaviors.

\section{References}

Cohen W M, Klepper S (1992). The anatomy of industry of R\&D intensity distribution. American Economics Review, 82: 777-799

Cohen W M, Levin R C, Mowery D C (1987). Firm size and R\&D intensity: A re-examination. The Journal of Industrial Economics, 35(4): 543-563

DeBresson C (1999). An entrepreneur cannot innovate alone: Networks of enterprises are required. DRUID Conference on Systems of Innovation in Aalborg, Denmark

Freeman C (1991). Network of innovation, a synthesis of research issues. Research Policy, 20 (5): 499-514

Griliches Z (1984). R\&D, Patents and Productivity. Chicago: University of Chicago Press

Harryson S (2004). 日本的技术和创新管理 (Japanese Technology and Innovation Management: From Know-how to know-who). 北京: 北京大学出版社

$\mathrm{Hu}$ A G (2004). Ownership, government $R \& D$, private $R \& D$, and productivity in Chinese industry. Economics of Innovation and New Technology, 13(1/2)

Hu A G Z (2001). Ownership, government $R \& D$, private $R \& D$ and productivity in Chinese industry. Journal of Comparative Economics, 29(1):136-157

Kamien M I, Schwatz N C (1975). Market structure and innovation: A Survey. Journal of Economic Literature, 13(1):1-37

Krugman P, Venables A J (1995). Globalization and the inequality of nations. Quarterly Journal of Economics, 110(4): 857-880

Utterback J M (1999). 把握创新 (To Grasp Innovation). 北京: 清华大学出版社

Scherer F M (1965). Firm size, market structure, opportunity and the output of patented inventions. American Economic Review, (5): 1097-1126

Schmookler J (1966). Invention and Economic Growth. Cambridge, MA: Harvard University Press

Schumpeter J (1942). Capitalism, socialism and democracy. New York: Harper \& Brothers Press

Scott J T (1984). Firm versus industry variability in R\&D intensity, in Griliches Z (eds), R\&D, Patent and Productivity. Chicago: University of Chicago Press

Utterback J M (1974). Innovation in industry and diffusion of technology. Science, 183 (4125): $620-626$

White H (1980). A heteroskedasticity-consisitent covariance matrix estimator and a direct test for heteroskedasticity. Econometrica, 48(4): 817-838

Yasuda Takehiko (2005). Firm growth, size, age and behavior in Japanese manufacturing. Small Business Economics, 24: 1-15

安同良, 施浩 (An Tongliang, Shi Hao), Alcorta (2006). 中国制造业企业 R\&D 行为模式的观测 
与实证：基于江苏省制造业企业问卷调查的实证分析 (Survey and study of R\&D behavioral mode of China's manufacturing enterprises: An empirical analysis based on questionnaire of manufacturing enterprises in Jiangsu province). 经济研究, (2)

陈佳贵, 王钦 (Chen Jiagui, Wang Qin) (2005). 中国产业集群可持续发展与公共政策选择 (Sustainable development of Chinese industrial clusters and choice of public policy). 中国工 业经济, (9)

池仁勇 (Chi Renyong) (2007). 区域中小企业创新网络的结点连结及其效率 (Crunode linkage and efficiency review of regional middle and small enterprises). 管理世界, (1)

刘志彪 (Liu Zhibiao) (2007). 全球价值链中我国外向型经济战略的提升 (Improvement of Chinese Export-oriented Strategy in Global Value Chain). 中国经济问题, (1)

刘志彪, 张杰 (Liu Zhibiao, Zhang Jie) (2007). 全球代工体系下发展中国家俘获型网络的形成、 突破与对策: 基于 GVC 与 NVC 的比较视角 (Forming, breakthrough and strategies of captive network in developing countries at global outsourcing system: Based on a comparative survey of GVC and NVC). 中国工业经济, (5)

王缉慈 (Wang Jici) (2004). 关于发展创新型产业集群的建议 (Suggestions on development of innovation industrial clusters). 经济地理, (4)

吴延兵 (Wu Yanbing) (2006). R\&D 与生产率: 基于中国制造业实证研究 (R\&D and production efficiency: Empirical studies on Chinese manufacturing enterprises). 经济研究, (11)

朱恒鹏 (Zhu Hengpeng) (2006). 企业规模、市场力量与民营企业创新行为(Enterprise's size, market power and private enterprise's innovation behaviors). 世界经济, (12) 